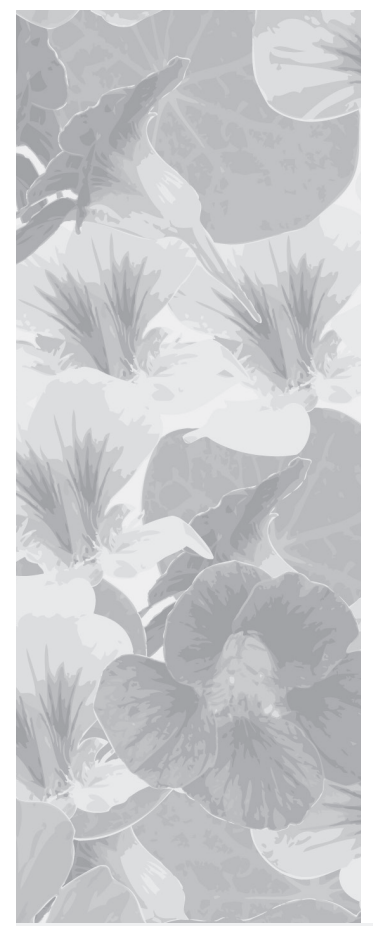

\title{
Estetologia medyczna, medycyna estetyczna, dermatologia estetyczna, chirurgia estetyczna, ginekologia estetyczna, stomatologia estetyczna - definicje i wzajemne relacje poszczególnych dziedzin
}

\begin{abstract}
Medical aesthetology, aesthetic medicine, aesthetic dermatology, aesthetic surgery, aesthetic gynaecology, aesthetic dentistry - definitions and mutual relationships between these areas
\end{abstract}

Radosław Śpiewak

Zakład Dermatologii Doświadczalnej i Kosmetologii, Wydział Farmaceutyczny Uniwersytet Jagielloński Collegium Medicum, Kraków

Estetol Med Kosmetol 2012; 2(3): 69-71

DOI: http://dx.doi.org/10.14320/EMK.2012.014

\begin{abstract}
Defining scientific disciplines is one of the most challenging tasks, especially if the intellectual need for systematizing science is interfered by conflicts of interest between competing professional groups. In "restorative" medicine, areas of competence are relatively well-defined both by the tradition and legal boundaries. For example, dermatology may be practiced only by a doctor who received a board certificate, which happens only after completing a strictly defined training and passing a state exam that ensures a required minimum of competences and skills in one's professional field. On the other hand, defining the "unregulated" specialties, such as "aesthetic medicine", "aesthetic dermatology", "aesthetic surgery", "aesthetic gynaecology" or "aesthetic dentistry" is substantially more difficult. Lack of "official" definitions of these areas may be considered as a weakness, however, it may also be perceived as a stillpresent opportunity for creating well-thought definitions that would imply high professional standards and levels of competence among their adepts. Definitions of "aesthetic medicine", "aesthetic dermatology", "aesthetic surgery" or "aesthetic dentistry" are proposed in the present article, along with the umbrella term "medical aesthetology" that encompasses all medical procedures that are restricted to certified physicians, and whose sole or main purpose is to improve physical attractiveness of the customer, rather than treating diseases. As various "aesthetic" specialists utilize similar approaches and methods, attempts at defining clear boundaries of competences between overlapping areas inevitably foster conflicts of interests and hamper the much needed dialog within the professional community. The term "medical aesthetology" is relatively new, thus it has not been yet appropriated by any of the professional groups active in this field (e.g. dermatologists, surgeons, dentists, etc.) which creates a medium for an unrestricted exchange of ideas and experiences, without provoking old controversies. The definitions and mutual relationships of these terms discussed in this article.
\end{abstract}

Keywords: medical aesthetology, aesthetic medicine, aesthetic dermatology, aesthetic surgery, aesthetic dentistry, cosmetology, definitions

Stowa kluczowe: estetologia medyczna, medycyna estetyczna, dermatologia estetyczna, chirurgia estetyczna, stomatologia estetyczna, kosmetologia, definicje

Copyright @ 2012 the Authors (text) and Radosław Śpiewak (layout \& journal compilation). All rights reserved.

Tworzenie definicji dziedzin nauki wydaje się jednym z trudniejszych zadań, szczególnie jeśli na racjonalną potrzebę porządkowania wiedzy nakłada się spór o zakres kompetencji między konkurującymi ze sobą grupami zawodowymi. Zakresy dziedzin medycyny „naprawczej” są dość jasno określone z jednej strony przez tradycję, a z drugiej przez ramy prawne. Na przykład dermatologię uprawia lekarz, który uzyskał tytuł dermatologa po złożeniu państwowego egzaminu weryfikującego posiadanie kompetencji określonych w zatwierdzonym urzędowo programie specjalizacji, który obowiązuje wszystkich adeptów tej dziedziny. Dużo trudniej jest określić zakres „niesformalizowanych” dziedzin medycyny, takich jak ,medycyna este- tyczna”, „dermatologia estetyczna”, „chirurgia estetyczna”, ,ginekologia estetyczna” czy „stomatologia estetyczna”. Brak „urzędowych” definicji tych dziedzin może być postrzegany jako słabość, zarazem jednak otwiera szansę dla stworzenia dobrych definicji, porządkujących zakres kompetencji i gwarantujących wysokie standardy w obrębie definiowanej dziedziny. Jak na razie szansa ta nie została należycie wykorzystana. Dość powiedzieć, że żaden z polskich podręczników mających „medycynę estetyczną” w tytule, nie zawiera definicji tego pojęcia [1-3]. Również oficjalne słowniki medyczne nie zawierają definicji interesujących nas dziedzin medycyny. 
Podobnie jest zresztą z kosmetologią - nieliczne opublikowane definicje mają zwykle doraźny charakter i służą przekazaniu konkretnej tezy autora, zaś wyjęte z kontekstu danego opracowania mogą być wręcz źródłem nieporozumień [4]. Definicje dostępne w literaturze niefachowej niekiedy wprowadzają chaos zamiast porządkować. Skrajnym przykładem jest definicja kosmetologii z encyklopedii PWN, która głosi że kosmetologia to „kosmetyka lekarska, dziat dermatologii zajmujacy się utrzymywaniem i przywracaniem urody ciała, gt. twarzy, jest zwiazana m. in. z endokrynologia, chirurgia, medycyna wewnętrzna, którego zasadniczymi metodami sa fizykoterapia, balneoterapia, metody farmakologiczne, higiena życia i odżywiania oraz kosmetyczne zabiegi chirurgiczne" [5]. Z punktu widzenia definicji specjalności lekarskich nie da się obronić sformułowania, że kosmetologia jest działem dermatologii, a już zupełnie kuriozalnie brzmi twierdzenie, że zasadniczymi metodami kosmetologii są farmakoterapia oraz zabiegi chirurgiczne. Trzymając się litery tej definicji, kosmetologią mogliby się parać wyłącznie lekarze dermatolodzy, co z kolei pozostaje w sprzeczności ze standardami Ministerstwa Nauki i Szkolnictwa Wyższego określającymi wymagania wobec kandydatów oraz tryb kształcenia z zakresu kosmetologii [6]. Stworzenie ogólnie akceptowalnej definicji kosmetologii, która odzwierciedlałaby obecny stan wiedzy i praktyki, a zarazem była kompatybilna ze standardami kształcenia wydaje się palącą koniecznością, jednak nie jest to celem niniejszego artykułu. Warto jedynie podkreślić, że w zakresie poznawczo-opisowym kosmetologia posługuje się metodologią bardzo zbliżoną do estetologii medycznej, zasadnicze różnice występują natomiast w zakresie interwencji stosowanych w ramach obu tych dziedzin, co zostanie omówione poniżej.

Pojęcia „medycyna estetyczna”, „dermatologia estetyczna”, „chirurgia estetyczna” czy „,stomatologia estetyczna" wydają się dość zrozumiałe intuicyjnie, ponieważ większość ludzi wie, czym zajmuje się medycyna, dermatologia, chirurgia czy stomatologia. W najprostszym ujęciu można zatem przyjąć, że przymiotnik ,estetyczna" do określenia odpowiedniej dziedziny dodaje się w przypadku, gdy działania lekarza służą poprawie atrakcyjności fizycznej (urody), a nie zapobieganiu lub leczeniu chorób. Zatem zgodnie z proponowanym podziałem specjalista dermatolog zajmujący się poprawianiem atrakcyjności a nie leczeniem chorób może być określony jako ,dermatolog estetyczny”, stomatolog zajmujący się poprawą wyglądu uzębienia a niekoniecznie funkcji może być uznany za „stomatologa estetycznego", a specjalista chirurg wykorzystujący swoje rzemiosło w celu poprawy wyglądu pacjenta - za „chirurga estetycznego". W tym ostatnim przypadku sytuacja jest komplikowana przez fakt, że istnieje certyfikowana przez państwo specjalizacja z chirurgii plastycznej.
Jej zakres definiuje się jako „dział chirurgii zajmujący się usuwaniem zniekształceń organicznych i przywracaniem sprawności ruchowej" [7], co stawiałoby tę dziedzinę po stronie medycyny naprawczej, jednak obserwacje z życia codziennego wydają się sugerować, że zachodzenie obszarów chirurgii plastycznej i „,chirurgii estetycznej” jest znaczne. Pojawia się także pytanie o sens wyróżniania aż tylu specjalności ,estetycznych”, skoro pojęcie „medycyna” jest najszersze i obejmuje również dermatologię, chirurgię oraz stomatologię? Jedną z możliwych odpowiedzi jest, że w medycynie „naprawczej” specjalność „medycyna ogólna” traktowana jest jako odrębna gałąź medycyny, której zakres w niewielkim stopniu pokrywa się z wymienionymi specjalnościami szczegółowymi. Dlatego określenie „medycyna estetyczna” można przez analogię rozumieć jako ,(ogólna) medycyna estetyczna”.

Podsumowując, poszczególne specjalności w swym „estetycznym” wariancie posługują się środkami typowymi dla danej „oficjalnej/naprawczej” dziedziny medycyny, a różnią się zaledwie celem działań lekarza czyli poprawą atrakcyjności fizycznej, a nie zapobieganiem czy leczeniem chorób. Kontynuując powyższą linię rozumowania, można przez analogię do medycyny ogólnej przyjąć także, że „(ogólną) medycyną estetyczną" zajmują się lekarze nie-dermatolodzy, nie-stomatolodzy i nie-chirurdzy, którzy stosują środki lekarskie (leki lub procedury nieinwazyjne lub o niewielkim stopniu inwazyjności) w celu poprawy fizycznej atrakcyjności swoich pacjentów. Ze względu na znaczne zachodzenie obszarów kompetencji i potrzebę dialogu między środowiskami, w celu ułatwienia komunikacji i przeciwdziałania zamykaniu się środowisk w małych, hermetycznych grupach proponuje się stosowanie terminu nadrzędnego ,estetologia medyczna” łączącego metody wszystkich wymienionych specjalności, a ponadto stanowiącego platformę partnerskiego dialogu z przedstawicielami kosmetologii (ryc. 1). W świetle powyższych wywodów, w razie gdyby w przyszłości miała się pojawić certyfikowana przez państwo specjalność, określenia „estetologia medyczna” dla dziedziny i „lekarz estetolog” dla specjalisty wydają się najbardziej odpowiednie.

\section{Definicje}

Estetologia medyczna (łac. aesthetologia medica, ang. medical aesthetology) to dziedzina nauki zajmująca się badaniem, opisywaniem, pielęgnowaniem, przywracaniem oraz kreowaniem za pomocą środków medycznych piękna ciała ludzkiego rozumianego jako atrakcyjność fizyczna. W zakresie poznawczo-opisowym dziedzina ta opiera się na metodologii nauk przyrodniczych (medycyny, biologii, biofizyki), antropologii i antropometrii, socjologii, psychologii oraz estetyki i filozofii. W zakresie interwencyjnym celem esteto- 
logii medycznej jest poprawa fizycznej atrakcyjności człowieka za pomocą metod typowych lub zastrzeżonych dla medycyny (leki, procedury i zabiegi), dietetyki, rehabilitacji oraz fizykoterapii. Rycina 1 przedstawia główne obszary estetologii medycznej.

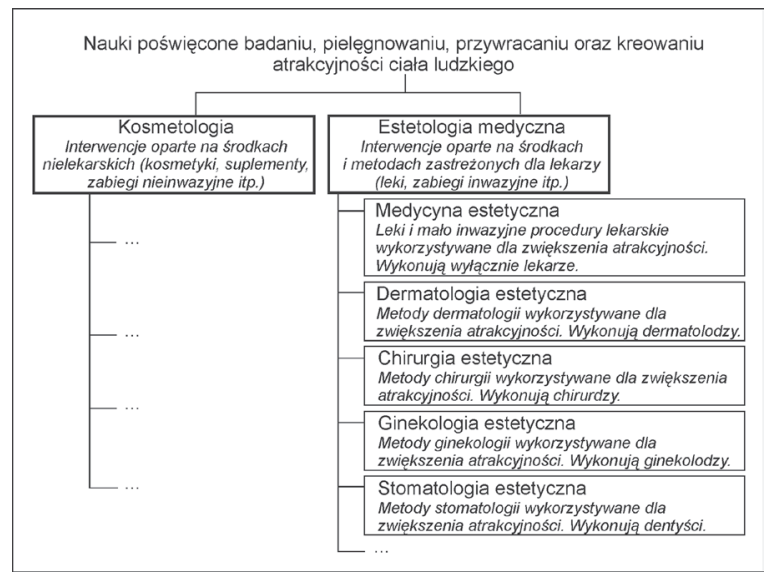

Rycina 1. Schemat wzajemnych zależności definiowanych pojęć. Ze względu na podobieństwo metod badawczych stosowanych przez porównywane dziedziny, na schemacie zostały uwypuklone różnice w zakresie stosowanych interwencji

Medycyna estetyczna (łac. medicina aesthetica, ang. aesthetic medicine) to dział estetologii medycznej obejmujący procedury, których stosowanie jest prawnie dopuszczalne wyłącznie przez lekarzy posiadających prawo wykonywania zawodu, takie jak ordynacja leków wydawanych z przepisu lekarza oraz zabiegi nieinwazyjne lub o niewielkim stopniu inwazyjności, których wyłącznym lub głównym celem jest poprawa fizycznej atrakcyjności pacjenta.

Dermatologia estetyczna (łac. dermatologia aesthetica, ang. aesthetic dermatology) to dział estetologii medycznej praktykowany przez lekarzy dermatologów środkami z zakresu ich specjalności podstawowej, których wyłącznym lub głównym celem jest poprawa fizycznej atrakcyjności pacjenta.

Chirurgia estetyczna (łac. chirurgia aesthetica, ang. aesthetic surgery) to dział estetologii medycznej praktykowany przez lekarzy chirurgów środkami z zakresu ich specjalności podstawowej, których wyłącznym lub głównym celem jest poprawa fizycznej atrakcyjności pacjenta.

Ginekologia estetyczna (łac. gynaecologia aesthetica, ang. aesthetic gynaecology) to dział estetologii medycznej praktykowany przez lekarzy ginekologów w obszarze kobiecych narządów płciowych środkami z zakresu ich specjalności podstawowej, których wyłącznym lub głównym celem jest poprawa fizycznej atrakcyjności pacjentki.
Stomatologia estetyczna (łac. stomatologia aesthetica, ang. aesthetic dentistry) to dział estetologii medycznej praktykowany przez lekarzy dentystów (stomatologów) środkami z zakresu ich specjalności podstawowej, których wyłącznym lub głównym celem jest poprawa fizycznej atrakcyjności pacjenta.

\section{Piśmiennictwo}

1. Redaelli A, Ignaciuk A (red.): Medycyna estetyczna. Wydawnictwo Medycyna Estetyczna, Warszawa 2010: 1-379.

2. Mamcarz B, Prandecka D (red.): Medycyna estetyczna w praktyce. Tom 1. Medical Education, Warszawa 2010: $1-142$.

3. Mamcarz B, Prandecka D (red.): Medycyna estetyczna w praktyce. Tom 2. Medical Education, Warszawa 2010: $1-163$.

4. Noszczyk M: Kosmetologia pielęgnacyjna i lekarska. PZWL, Warszawa 2010: IX.

5. Nowa Encyklopedia Powszechna PWN. Tom 3. Wydawnictwo Naukowe PWN, Warszawa 1998: 507.

6. Ministerstwo Nauki i Szkolnictwa Wyższego: Standardy kształcenia na kierunku Kosmetologia 2007. URL: http:// www.bip.nauka.gov.pl/_gAllery/63/88/6388/Zalacznik_ nr_4-kosmetologia.pdf (dokument elektroniczny, stan na dzień 25.03.2012).

7. Polska Akademia Nauk, Wydział Nauk Medycznych: Wielki słownik lekarski. Wydawnictwo Lekarskie PZWL, Warszawa 1996: 166.

\section{Finansowanie i konflikt interesów}

Autor deklaruje niewystępowanie konfliktu interesów w odniesieniu do treści zawartych w niniejszej pracy.

\section{Adres do korespondencji}

dr hab. med. Radosław Śpiewak, profesor UJ Zakład Dermatologii Doświadczalnej i Kosmetologii Wydział Farmaceutyczny UJ ul. Medyczna 9, 30-688 Kraków Tel.: 1262058 30, Fax: 126205645

E-mail: spiewak.eu@gmail.com

Data złożenia: 27.02.2012

Data akceptacji: 23.04.2012 